INTERNATIONAL JOURNAL OF RESEARCHES IN BIOSCIENCES, AGRICULTURE AND TECHNOLOGY C VISHWASHANTI MULTIPURPOSE SOCIETY (Global Peace Multipurpose Society) R. No. MH-659/13(N) www.ijrbat.in

\title{
SUSTAINABLE COEXISTENCE OF HUMAN WITH ELECTROMAGNETIC RADIATION OF MOBILE AND MOBILE TOWERS.
}

\author{
Sanyogita Verma ${ }^{1}$ and Pramod R. Chaudhari ${ }^{2}$ \\ ${ }^{1}$ Anand Niketan College, Anandwan, Warora, Maharashtra, India. \\ ${ }^{2}$ ex-Deputy Director, National Environmental Engineering Research Institute (CSIR-NEERI), \\ Nagpur, Maharashtra, India. \\ ${ }^{1}$ sanyogitaverma15@gmail.co; mob: +919579561692 \\ 2pr.chaudhari66@gmail.com; mob: +919766540848.
}

\begin{abstract}
:
The people everywhere are exposed to natural non-ionizing radiation levels due to the presence of radionuclides in the earth. Human body is acclimatized to these radiations up to certain level, above which it imparts health problems. The natural radiation level is increased by man-made radiations due to use of electronic gadgets and cell phone towers. The cell phones and gadgets are getting constantly upgraded, resulting in introduction of new ones in market, enhancing total radiation levels. The radiations emitted by diverse electronic equipments include radio waves, microwaves, and extremely low frequency waves. Thermal radiation from hot objects and electromagnetic field due to electric current flowing through power lines and electric appliances also has minor contribution to total radiation. The average natural radiation level to population is $2.299 \mathrm{mSv}$ for India and $2.455 \mathrm{mSv}$ for world population, which is now observed to be increased by around 100 times. There are public health problems over certain level of exposure, for which international norms and stricter Indian norms are available for mobiles and mobile towers, which are major contributor to radiation. The relevant information on health impact, preventive measures, and clarification of certain myths are available on the website of Department of Telecommunications (DoT), Govt. of India.
\end{abstract}

Keywords: Electronic Gadgets, Non-Ionizing Radiation, Impact, Public Health, Regulations, Prevention.

\section{Introduction}

The troposphere air includes basic major elements like oxygen, carbon-di-oxide, nitrogen, and other gases in minor quantities and water vapour. These are essential for biogeochemical cycles of nutrients and energy for human life. Apart from these elements, another lesser known but of important natural component of human environment is nonionizing radiation. These non-ionizing radiations come from naturally occurring radio isotopes present in the earth, and from nonionizing radiation of solar spectrum. The human body is well acclimatized to these natural radiations up to certain threshold level.

The industrial development in the world adds air pollutants to pristine environment, at higher levels with the intensification of the developmental activity. Thus, the industrial air pollution plays major part in disturbing the environmental balance, human health, and sustainable development. The countries in the world are now trying to reduce the environmental pollution through technological intervention and by introducing various regulation and standards.

The radiation pollution is now added to the list of environmental pollutants. The incidence of radiation pollution, especially non-ionization radiation, is recent, with the introduction of electronic gadgets in public life in this electronic age, since around last three decades. These man-made radiations have enhanced the natural level of radiation. Research has shown that this type of radiation is not benign or harmless to the human body, especially children, pregnant women and senior citizens and it is linked to fatigue, dizziness, mental fog, etc.

The people are well aware of the ionizing radiation from the incidents of atom bomb attack on Hiroshima and Nagasaki, nuclear tests, and accidents in nuclear power plants, having serious environmental and public health impacts for short exposure as well as long chronic exposure. The people are now interested in getting more information about non-ionizing radiations from various sources, which affect human health.

\section{Benefits and Popularity of Electronic Equipments}

The electronic age has gifted many simple to highly sophisticated equipments and gadgets which are continuously upgraded especially mobiles, i-phones, laptops, computers etc. These equipments have made the life simple and interesting due to fast communication and availability of immense worldwide information on every subject handy at any time and at any place. Cell phones provide an instrument to interface with internet, vast worldwide information, communication with friends, family and co-workers, and useful in emergency especially for ladies in danger. Growth in internet will have multiple benefits 
like internet commerce, delivery of financial and healthcare services as well as egovernance.

India's mobile phone subscriber base has crossed the 1 billion users mark as per the data released recently by the country's telecom regulator [1]. India has become the world's third-largest base in this regard after China and the United States [2] that is projected to grow at approximately 3 percent over the next 4-5 years [3]. A large number of the subscribers will become Smartphone users in near future. Moreover, Government of India is promoting digitization through an ambitious project called "Digital India". There will be an upward trend with an increase in spectrum demand of $4 \mathrm{G}$ and more sophisticated networks.

\section{Natural Sources of Non-Ionizing Radiation}

The terrestrial component of radiation mainly originates from the primordial radionuclides (238U, 235U, 226Ra, 232Th, and 40K) that were existed on the earth's crust since its formation [4]. The dose from terrestrial sources varies in different parts of the world depending upon the concentrations of uranium and thorium in their soils. These radiations cause outdoor and indoor exposure of human body to radiations, also exposure to the internal radiation due to radionuclides accumulated in human body. Indoor radiations are caused when these naturally occurring radionuclides in rocks, soil and groundwater decay into the radioactive materials. The radon gas (radon222) formed by decay product of uranium-238 and thoron gas (radon-220) produced during the decay series of thorium-232 seep out of the earth into houses through cracks and holes in the foundation of the buildings as well as through groundwater supply and cause indoor exposure [5]. Some of the radionuclides from these sources may be transferred to human beings through food chain or inhalation [5]. At least $20 \%$ of our homes and offices are impacted by natural ground radiations and its enhanced levels due to man-made sources of radiation.

Man-Made Sources of Non-Ionizing Radiation Major man-made sources of non-ionizing radiation are radiation emitting from electronic equipments, cell phones, cell towers, and electromagnetic radiations from electric currents in power lines and electric devices. Non-ionizing radiation consists of a series of energy waves composed of oscillating electric and magnetic fields traveling at the speed of light. Non-ionizing radiation in sunlight spectrum includes electromagnetic waves at the longer wave length of the spectrum below ultraviolet (UV), including visible light, infrared (IR), microwave (MW), radio frequency (RF), very low frequency (VLF) and extremely low frequency (ELF) [6]. The non-ionizing radiations have very important different applications in practical life [7], as summarized below.

Microwaves are applied in cell phone, telephones, radars, airport scanners, microwave ovens, earth remote sensing satellite, radio and satellite. Microwaves are electromagnetic waves ranging from as long as one meter to as short as one millimeter (frequencies between $300 \mathrm{MHz}(0.3 \mathrm{GHz})$ and $300 \mathrm{GHz}$ ).

Radio waves are used for fixed and mobile radio communication, cell phones, tablets, computers, laptops, broadcasting, radar and other navigation systems. Other applications are satellite communication, computer networks and innumerable other applications. The wavelengths of radio waves are longer than infrared light. Different frequencies of radio waves have different propagation characteristics in the earth's atmosphere, long waves may cover a part of earth very consistently, shorter waves can reflect off the ionosphere and travel around the world, and much shorter wavelengths bend or reflect very little and travel in a sight line.

People at large are exposed to these radiations constantly. Most of the people get addicted to cell phone whether it is an Android, an iPhone, a Blackberry, or a basic flip phone, and handle them even when phone is not ringing or vibrating.

Very low frequency (VLF) ( 3 to $30 \mathrm{kHz}$ ) is called as myriameter band as the wavelengths range from ten to one myriameter. There is not much band width in this band of the radio spectrum, only very simplest signals are used, such as for radio navigation.

Extremely low frequency (ELF) is the range of radiation frequencies from $300 \mathrm{~Hz}$ to $3 \mathrm{kHz}$, considered to be in ULF range.

Electromagnetic field $(\mathrm{EMF})$ radiation is created by electric current, which is also of important contributor to radiation. Human body is exposed to these radiations in outdoor and indoor environment. Thermal radiation is radiated in the form of electromagnetic waves by the hot objects. Infrared radiations from household heater, infra-red light lamps, or kitchen oven are examples of thermal radiation. Part of electromagnetic spectrum of 
thermal radiation may be ionizing, if the object is hot enough.

\section{Total Amount of Radiation Dose to Human Being}

Average contribution towards radiation exposure from various sources are radon $(55 \%)$, radiation from rocks and soils $(8 \%)$, cosmic rays $(8 \%)$, internal body sources $(11 \%)$, medical $(15 \%)$, consumer products $(3 \%)$ and other (<1\%) [4] (Fig. 1) [4].

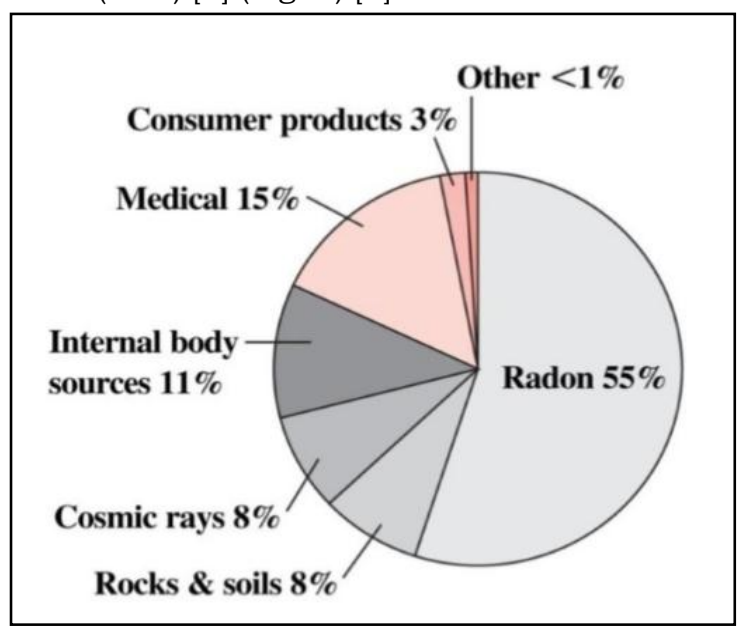

Figure 1: Average contribution towards radiation exposure from various sources [4].

The unit of measurement used for the biological effect of radiation on the human body is the milliSievert ( $\mathrm{mSv}$ ). The estimated average annual effective dose (for different natural sources) to Indian population is 2.299 $\mathrm{mSv} / \mathrm{y}$ (milliSievert/y) and to world population is $2.455 \mathrm{mSv} / \mathrm{y}$. Percent contributions from different natural sources are, radon and thoron contribute highest $(51.9 \%$ to $53.7 \%$ ) followed by terrestrial $(16.5 \%$ to $19.6 \%)$, external exposure (cosmic radiation) (15.4\% to $15.5 \%$ ), and internal exposure (inhalation) $(0.41 \%$ to $0.65 \%)$. This level of natural nonionizing radiation in human environment has been increased due to man-made radiations by more than 100 times in the last 15 years.

Parts of Kerala and Tamil Nadu have high background radiation areas because of the presence of large quantities of monazite in the soil. Thorium content in monazite ranges from 8-10.5\% [6] resulting in dose rates as high as $32,500 \mu \mathrm{Sv}$ (3.25 $\mathrm{mSv})$ [4]. The regions of Maharashtra and South Gujarat are covered by the Deccan lava basalt with very low radioactivity. The Gangetic alluvial regions covering parts of Uttar Pradesh, Bihar and West Bengal have somewhat higher radioactivity. The granite region of Andhra Pradesh exhibits quite high levels of the primordial radioactivity.
As far as lethal dose of radiation is concerned, very large doses over $5,000 \mathrm{mSv}$, received by the entire body over a short time, result in death within a few days. Doses over $100 \mathrm{mSv}$ can have a harmful effect on humans, such as a higher incidence of developing cancer. At even lower doses of radiation, below $100 \mathrm{mSv}$, there is lot of uncertainty about the overall effects. However, the risk of adverse effects in this dose range is very low. The risk in this low dose range is proportional to the amount of dose received by the body [8].

\section{Electromagnetic Fields Around Electric Current}

Electromagnetic fields are created by electric currents. Greater the current, stronger is the magnetic field. With the increase in number of consumers using electricity and electric instruments, electromagnetic field is assuming considerable importance from public health point of view. The electric current and resulting electromagnetic fields are at right angles to each other. Electromagnetic fields are commonly found around high voltage power lines; neighbourhood transmission lines, grounding systems that protect residents from lightning, electric shock that can result from faulty appliances, the operation of common electrical appliances including microwave ovens, electric ranges, aquariums, table fans, electric space heaters, computer monitors, electric clocks, radios, heated waterbeds, electric blankets, hair dryers, cellular phones, video display terminals [9].

\section{Health Problems Pertaining to Mobile} Phone Use [10, 11, 12]

The non-ionizing radiofrequency energy emitted by mobiles and similar gadgets is generally more than 1000 times higher than from base stations [13]. These radiations are absorbed by the tissues close to the mobile phone [14]. There is, thus, great likelihood of any adverse effect due to handsets. Scientists have reported health effects of using mobile phones including changes in brain activity, reaction times, and sleep patterns. However, these effects need to be confirmed by more studies. WHO has promoted further research on long term impact on health, desirably for 15 years.

Mobile phones are carelessly used and are kept at several places, or handled by dirty hands, where it gets contaminated with germs. One in six cell phones is contaminated with some sort of faecal matter or E. coli due to carelessly washed hands, as observed in 2011 by researchers in University of London. If 
ingested, E. coli can cause fever, vomiting, and diarrhea. The researcher at South University, Columbia recorded Staphylococcus aureus in swabbing sample of 60 phones. This microbe quickly turns into deep, painful abscesses.

Many people invite accident hazard by walking or driving while talking on cell phone. Most of the drivers drive while talking on cell phone.

The vision problems due to reading small text over bright screen on mobiles, computers, smart phones and other hand held devices include eye redness, irritation, dry eyes, blurred vision, chronic pain, back pain, neck pain, inflammation of joints and headaches due to arching of body or holding body in a strange posture during cell phone use

Mobile phones also cause electromagnetic interference when used very close to some medical devices (pacemakers, implantable defibrillators, and certain hearing aids) or aircraft electronics causing interference in their operation. The risk is much reduced for $3 \mathrm{G}$ phones and newer equipments.

\section{Prevention and Protection from Cell Phone Radiations [15]}

- Limit time on the cell phone and use phones only to necessary calls

- The cell phones must be handled hygienically, for not to get contaminated. Cell phones can be cleaned with the help of dry towel effectively.

- Traffic hazards are preventable by putting the mobile away while driving or crossing the street, or come to halt at safe place and then talk on mobile.

- Digital eye strain may be prevented by reducing the glare, cleaning the screen, dimming the surrounding lighting, keeping adequate distance between eyes and screen, and follow the "20-20-20" rule. Take a 20second break every 20 minutes using an electronic device and look at something 20 feet away.

- Replace the current old version of cell phone by good latest quality phone with a lower emission.

- Do not put the phone on the body or on waist during use, as the radio electromagnetic waves emitted by the phone are absorbed by the soft tissues of the body.

- Keep the phone away from babies, children, and pregnant women.

- Use the phone after getting it connected.

- Use speaker phone while speaking on cell phone by keeping it away a hand's length; or use wired handset rather than holding the phone to the head, or use Bluetooth emitter.
- For best protection, use cell phone for emergencies, keep cell phone off when not in use and use shielded pouch to keep it in.

- Use the phone when it has maximum number of bars, indicating the best reception. When signal quality is poor, the phone emits more radiation.

- Do not use cell phone in elevators, cars, trains, or planes, as cell phones draw more power and emit more radiation, in enclosed metal spaces.

- When at home, use a wired landline, or phone line internet. Cordless phones connected to a landline can emit radiation much like cell phones; remove all cordless phones from home.

- Use SMS service instead of calling, as far as possible.

- Many radiation shields available in market may hamper reception causing the phone to emit more radiation. Bullion mesh shielding material may be used after testing effectiveness with a field meter that measures in microwave range. Purchase a scientifically validated electromagnetic field protection device. This will strengthen the bioenergy field and immune system against the harmful effects of electromagnetic fields.

- Support the body health with proper nutritional diet with anti-oxidants such as Tulsi leaves extract, catalase, glutathione, and Coq10. You can also supplement with melatonin, zinc and Gingo biloba.

- Keep the wireless router in little used room and out of bedroom, or turn off during night.

- Disable your computer's wireless connectivity software, including Bluetooth, airport and the like. Otherwise the computer will continuously send out electronic "handshakes" exposing to more radiation frequency.

- Smart meters are associated with symptoms of radiation-illness, including sleeping problems, ringing in ears, skin rashes, headache, migraines, swollen sinuses, ear pain, breathing problems, and more. So do not sleep near or in the same room of smart meter.

The developed countries like France, Taiwan, Israel, and Italy have passed national laws banning WiFi and use of wireless devices in nursery schools for protection of children from radiations [16].

"Envirochip" Radiation Protection for
Wireless Devices: The technological
intervention "Envirochip" for radiation


protection from electronic devices have been developed by various companies in India. The Envirochip is available on-line in different suitable sizes for mobile phones, computers, tablets, Wi-Fi routers, laptops, desktops, CPUs, and other personal electronic gadgets. These products have been used by large number of establishments like industries, airports, power plants, offices, educational institutions, stores, hospitals, hotels, homes etc. and reported better health, improved interpersonal relationships and reduction in machinery breakdowns.

Constant waves (radiation) emitted from electronic gadgets disturb the cellular communication of the body. Envirochip generated random waves at higher frequencies, which convert the constant microwaves from electronic gadgets into random form to make them compatible with the body's waveforms, which is no longer harmful for the human body [17].

The Envirochip takes care of the non-thermal aspects of radiation emitted from electronic gadgets by changing the harmful nature of electromagnetic radiations emitted by them. It does not affect the signal quality or functioning of the electromagnetic gadgets. The Envirochip is made from a mix of metals and embedded software. Since the emission of EMR cannot be stopped, deflected or reduced, the Envirochip changes the characteristics of the radiation by emanating frequencies between 500-600 terahertz, while communication devices operate in the 8004000 megahertz range. The chip operates at a higher frequency and generates random signals which superimpose and neutralizes the EMR rays. This changes their nature of radiofrequency from constant wave to random wave and renders them ineffective to human cells.

\section{Radiations from Cell Phone Towers (Base Stations)}

Radiation from cell phone towers (mobile towers or telecom towers) is a relatively new kind of environmental pollution, which is unseen and subtle pollutant that may be affecting the life forms in many ways. They may be free-standing towers or mounted on existing structures, such as tall buildings, water tanks etc. and may be very near to residential areas. The comprehensions about the health hazards on exposure to these radiations have been expressed by public and experts from time to time.
The widespread use of cell phones has led to installation of cell phones towers (also called as base stations) in many localities. Cell phones communicate with nearby cell phone towers mainly through radiofrequency (RF) waves (energy in electromagnetic spectrum between FM radio waves and microwaves). $\mathrm{RF}$ waves can be absorbed by human tissues and may have heating effect at very high energy. But the levels of energy used by cell phones and towers are much lower having insignificant effect on human tissue. Base station antennas use much lower levels of RF than those from radio and television broadcast stations [18].

The antennas are mounted high above ground level on the cell phone tower, The energy from a cell phone tower antenna is directed toward the horizon (parallel to the ground), with some downward scatter. The signals are transmitted intermittently, rather than constantly. The amount of energy decreases rapidly as the distance from the antenna increases. At ground level near typical cellular base stations, the amount of RF energy is thousands of times less than the limits for safe exposure set by the regulatory authorities. Therefore, there are least chances that the persons on the ground could be exposed to RF levels above norms [5].

The level of RF energy inside buildings where a base station is mounted is generally much lower than the levels outside, as the wood or cement block in the construction further reduces the exposure level of $\mathrm{RF}$ radiation by a factor of about 10. The energy level behind an antenna is hundreds to thousands of times lower than in front. Therefore, if an antenna is mounted on the side of a building, the exposure level in the room directly behind the wall is typically well below the recommended exposure limits.

Cell phone towers do not pose health hazard because the energy level of RF is not enough to break chemical bonds in DNA molecules, so cannot lead to cancer. RF waves have long wavelengths that could not be concentrated enough to affect individual cells in the body.

The level of RF waves present at ground level near cell phone tower is very low, well below the recommended limits and very much similar to the background levels of RF radiation in urban areas from other sources, such as radio and television broadcast stations.

Very few human studies have focused specifically on cell phone towers and cancer 
risk. The results of available studies indicate no correlation between cancer or health problems or to formation of tumors and exposure to cell phone tower radiations [19]. The exposure from cell phone tower is many times lower than the exposure from using a cell phone.

The three expert agencies that usually classify cancer-causing exposures (carcinogens) - the International Agency for Research on Cancer (IARC), The National Toxicology Program (NTP), and the US Environmental Protection Agency (EPA) - have not classified cell phone towers specifically as to their cancer-causing potential.

\section{Clarification on Radiation from Base Mobile Stations}

During Public Awareness Programme [20], the Secretary of Department of Telecommunications (DoT), Government of India assured that the radiation from mobile towers in India are within the safe levels and norms prescribed by DoT as well as those of International Commission on Non-ionizing Radiation Protection (ICNIRP) and recommended by the World Health Organization (WHO). There is no scientific evidence to show relation between the mobile tower radiation and health problems (Expert Committee formed on the advice of Allahabad High Court and WHO). Several High Courts in cases related to the effects of the radiation from cell phone towers have given judgments whereby they have dismissed petitions. International Agency for Research on Cancer, during their studies, did not find any indication that environmental exposure to RF fields, such as from the base stations, increases the risk of cancer or any other disease.

\section{Protection from Radiations of Cell Phone Towers}

Following measures are suggested to prevent exposure to high level of radiation from cell phone towers [21].

- Use of low power radiating antennae or distributed antennae systems to make it more efficient and environmentally sensitive.

- Smart meters or other measuring device should be installed near mobile towers. If radiation exceeds, fine may be imposed.

- Online system for monitoring the radiation levels should be set up in various cities.

- DoT and other key government departments should conduct audits of cell phone towers more frequently and efficiently.
- Install some kind of electromagnetic shielding technology around cell phone towers which may reduce the EMR exposure to nearby people.

\section{Stricter Indian Radiation Norms}

DoT, GoI introduced toughest electromagnetic field radiation norms after 1st September 2012 for cell phone towers (Table 1) and for the level of Specific Absorption Rate (SAR) for mobiles (Table 2), which are 10 times stricter than the international norms prescribed by the International Commission for Non-Ionizing Radiation Protection (ICNIRP).

Table 1: Standard for radiation norms for mobile

\begin{tabular}{lll} 
Frequency & $\begin{array}{l}\text { ICNIRP } \\
\text { Radiation } \\
\text { Norms }\end{array}$ & $\begin{array}{l}\text { towers } \\
\text { Revised DoT Norms } \\
\text { September } \mathbf{2 0 1 2}\end{array}$ \\
\hline $\mathbf{9 0 0} \mathbf{~ M H z}$ & $4.5 \mathrm{watt} / \mathrm{sq} \mathrm{m}$ & $0.45 \mathrm{watt} / \mathrm{sq} \mathrm{m}$ \\
\hline $\mathbf{1 8 0 0} \mathbf{~ M H z}$ & $9.0 \mathrm{watt} / \mathrm{sq} \mathrm{m}$ & $0.90 \mathrm{watt} / \mathrm{sq} \mathrm{m}$ \\
\hline $\mathbf{2 1 0 0} \mathbf{~ M H z}$ & $10.5 \mathrm{watt} / \mathrm{sq} \mathrm{m}$ & $1.05 \mathrm{watt} / \mathrm{sq} \mathrm{m}$ \\
\hline
\end{tabular}

Table 2: SAR levels for mobiles

\begin{tabular}{lll}
$\begin{array}{l}\text { Frequency } \\
\text { (10 MHz to } \\
\text { 10 GHz) }\end{array}$ & $\begin{array}{l}\text { ICNIRP } \\
\text { SAR Limit }\end{array}$ & $\begin{array}{l}\text { Revised SAR Limit } \\
\text { effective from 1st } \\
\text { September 2012 }\end{array}$ \\
\hline $\begin{array}{l}\text { General } \\
\text { Public } \\
\text { exposure }\end{array}$ & $\begin{array}{l}\text { 2 watt } / \mathrm{kg} \\
\text { (averaged } \\
\text { over 10 gm } \\
\text { tissue) }\end{array}$ & $\begin{array}{l}1.6 \text { watt/kg } \\
\text { (averaged over 1 gm } \\
\text { tissue) }\end{array}$ \\
\hline
\end{tabular}

\section{Guidelines for Mobile Companies}

- It will be mandatory for manufacturers to display the SAR - level on each mobile handset like IMEI (International Mobile Equipment Identity) display from 01.09.2013.

- SAR Test Laboratory has been set up in the Telecom - Engineering Centre of DoT for testing of SAR value of mobile handsets imported/ manufactured in India.

- Telecom Enforcement Resource \& Monitoring (TERM) Cells of DOT have been entrusted with the job of conducting audit on the self certification furnished by the Service Providers. TERM Cell shall carry out test audit up to $10 \%$ of the BTS site on random basis and on all cases where there is a public complaint.

- Telecom Engineering Centre (TEC) has revised the Test Procedure for measurement of $\mathrm{EMF}$ for verification of EMF compliance for BTS towers in accordance with new standards effective from 1st September 2012.

- For non-compliance of EMF standards, penalty of Rs. 5 lakh is liable to be levied per BTS per Service Provider of Mobile Handsets.

\section{Guidelines for Setting up of Telecom Towers}

- Before installation of tower, the licensee company obtains siting clearance from DoT to ensure that no interference with other wireless 
users, no aviation hazards and no obstruction to any other existing microwave links.

- Telecom service providers have to obtain the necessary permission from the concerned local authorities/ Municipal Corporation before installation of tower.

- Ensure that no nearby buildings right in front of the antenna with height comparable to the lowest antenna on tower at a distance threshold as specified.

- Operators through actual peak traffic time measurements need to establish that exclusion zone (Table 3) does not cover areas with public exposure.

Table 3: Guidelines for distance from the antenna to the building/structure

\begin{tabular}{ccc}
\hline $\begin{array}{c}\text { Number of } \\
\text { multiple } \\
\text { antennas with } \\
\text { same orientation }\end{array}$ & $\begin{array}{c}\text { Building/structure distance } \\
\text { from the antenna (safe } \\
\text { distance) } \\
\text { (in meters) }\end{array}$ \\
\hline 1 & 20 \\
\hline 2 & 35 \\
\hline 4 & 45 & \\
\hline 6 & 55 & \\
\hline $\begin{array}{l}\text { Guidelines for Wall } \\
\text { mounted Antenna }\end{array}$ & Mounted / Pole
\end{tabular}

- Pole mounted Antenna height $\geq 5$ meter above ground / road level on flyovers.

- No residential place / office should be directly in front of the wall mounted antenna at a height comparable to the antenna in the exclusion zone.

- No restriction for installation of tower on / near specific buildings such as schools / hospitals / playground etc. as new tougher standards based on precautionary principles apply equally to all locations with human presence.

Public Outcry Against the Indian Norms

Table 4: Comparison of Recommended Norms by Global Bodies and Indian Norms

\begin{tabular}{|c|c|c|c|}
\hline Country & Institution & $\begin{array}{c}\text { Power } \\
\text { density } \\
\text { (mill watts } \\
\text { per m2) }\end{array}$ & Remark \\
\hline \multirow[t]{4}{*}{ Austria } & \multirow{4}{*}{$\begin{array}{l}\text { *Austrian } \\
\text { Medical } \\
\text { Association } \\
\text { (Adopted on } 3 \text { rd } \\
\text { March } 2012 \text { in } \\
\text { Vienna) }\end{array}$} & $\geq 1 \mathrm{~mW} / \mathrm{m} 2$ & $\begin{array}{l}\text { Very far } \\
\text { above } \\
\text { normal }\end{array}$ \\
\hline & & $\begin{array}{l}0.01- \\
1 \mathrm{~mW} / \mathrm{m} 2\end{array}$ & $\begin{array}{l}\text { Far } \\
\text { above } \\
\text { normal }\end{array}$ \\
\hline & & $\begin{array}{l}0.001-0.01 \\
\mathrm{~mW} / \mathrm{m} 2\end{array}$ & $\begin{array}{l}\text { Slight } \\
\text { above } \\
\text { normal }\end{array}$ \\
\hline & & $\begin{array}{l}\leq 0.001 \\
\mathrm{~mW} / \mathrm{m} 2\end{array}$ & $\begin{array}{l}\text { Within } \\
\text { normal } \\
\text { limits }\end{array}$ \\
\hline \multirow[t]{4}{*}{ Germany } & \multirow{4}{*}{$\begin{array}{l}\text { Baubio MAES, } \\
\text { Germany } \\
\text { Building } \\
\text { Biology } \\
\text { Evaluation } \\
\text { guidelines for } \\
\text { Sleeping Areas }\end{array}$} & $\geq 1 \mathrm{~mW} / \mathrm{m} 2$ & $\begin{array}{l}\text { Extreme } \\
\text { concern }\end{array}$ \\
\hline & & $\begin{array}{l}0.01- \\
1 \mathrm{~mW} / \mathrm{m} 2\end{array}$ & $\begin{array}{l}\text { Severe } \\
\text { concern }\end{array}$ \\
\hline & & $\begin{array}{l}0.001-0.01 \\
\mathrm{~mW} / \mathrm{m} 2\end{array}$ & $\begin{array}{l}\text { Slight } \\
\text { concern }\end{array}$ \\
\hline & & $\begin{array}{l}\leq 0.001 \\
\mathrm{~mW} / \mathrm{m} 2\end{array}$ & $\begin{array}{l}\text { No } \\
\text { concern }\end{array}$ \\
\hline
\end{tabular}

\begin{tabular}{|c|c|c|}
\hline \multirow[t]{4}{*}{ Sweden } & \multirow{4}{*}{$\begin{array}{l}\text { Bio-Initiative } \\
\text { Report } 2012\end{array}$} & $\geq 1 \mathrm{~mW} / \mathrm{m} 2$ \\
\hline & & $\begin{array}{l}0.01- \\
1 \mathrm{~mW} / \mathrm{m} 2\end{array}$ \\
\hline & & $\begin{array}{l}0.001-0.01 \\
\mathrm{~mW} / \mathrm{m} 2\end{array}$ \\
\hline & & $\begin{array}{l}\leq 0.001 \\
\mathrm{~mW} / \mathrm{m} 2\end{array}$ \\
\hline \multirow[t]{2}{*}{ India } & \multirow[t]{2}{*}{$\begin{array}{l}2012 \\
\text { September }\end{array}$} & $\begin{array}{l}450 \\
\mathrm{~mW} / \mathrm{m} 2\end{array}$ \\
\hline & & $\begin{array}{l}1000 \\
\mathrm{~mW} / \mathrm{m} 2\end{array}$ \\
\hline \multicolumn{3}{|c|}{$\begin{array}{l}\text { *Austrian Medical Association: irrespective } \\
\text { of the ICNIRP recommendation for acute } \\
\text { effect, the Austrian Medical association } \\
\text { benchmark applies to regular exposure of } \\
\text { more than four hours per day. }\end{array}$} \\
\hline
\end{tabular}

Some citizens expressed that the stricter norms adopted by India are far higher than norms followed by other countries, like Austria, France and UK (Table 4). It was felt that revision in norms to reduce health hazards to citizens should have been done by reducing actual permitted radiation levels from the antennae to $10 \%$ and not norms; or reducing the maximum power transmitted per antenna / site to 2 watts instead of 20 watts per antenna [22].

\section{Conclusion:}

The use of mobiles, I-phones, and many handheld electronic devices is tremendously increasing throughout the world due to their utility in communication under normal or emergency conditions and ease of interface with worldwide information apart from many other advantages. To cater to this service, the cell phone towers are also increasingly installed in urban and rural areas. The people were complaining about the health problems and were comprehensive about serious health hazards. However, the research has shown that the low power $\mathrm{RF}$ radiations from cell phones and Cell phone towers do not cause any serious health effect like cancer or tumor. The human body is acclimatized to the baseline natural radiation in troposphere. The uneasiness and chronic effects due to over exposure to higher $\mathrm{RF}$ radiations have been prevented by introducing stricter norms and guidelines for manufactures and users of mobiles and cell phone towers. The chronic effects may be prevented by taking simple precautions and using technological interventions like radiation shielding devices. 


\section{References:}

https://www.forbes.com/sites/saritharai/2016/ 01/06/india-just-crossed-1-billion-mobilesubscribers-milestone-and-the-excitements-justbeginning/

Rai Saritha (2016): India just crossed 1 billion mobile subscribers milestone and the excitement's just beginning. Forbes Asia, Jan 6, 2016.

https://www.epa.gov/radiation/radionuclides Wolfson Richard (2007): Essential University Physics, Vol. 2. Pearson Addison-Wesley.

Narayanan K.K., Krishnan D., Subba Ramu M.C. (1991): Population exposure to ionizing radiation in India. Indian Society for Radiation Physics, Kalpakkam Chapter, ISRP(K) - BR - 3 .

Ibrahiem N.M., Abd El Ghani A.H., Shawky S.M., Ashraf E.M., and Farouk M.A. (1993): Measurement of radioactivity levels in soil in the Nile Delta and Middle Egypt. Health Physics 64:Pp. 620-627.

Gupta P.K. (2016): Health effects of radioactive materials, Chapter 30 in Fundamental of Toxicology: Essential Concepts and Applications, Pp. 333-339. Academic Press.

https://www.medicalradiation.com/facts-aboutradiation/benefits-and-risks-of-

radiation/benefits-and-risks-of-ionizing-

radiation/

Bhattacharjee Sumana (2014): Protective measures to minimize the electromagnetic radiation, Advance in Electronic and Electric Engineering, 4(4): Pp. 375-380.

Newnam Jared (May 10, 2013): Health risks of using mobile phones, South University.

https://www.southuniversity.edu/whoweare/ne wsroom/blog/health-risks-of-using-mobilephones-137310.

Lizette Borreli (July 12, 2013): Consumer News Medical Daily.

Wikipedia (2017): Mobile Phone Radiation and Health. Wikipedia, last edited on 22 October 2017.

WHO (September 20, 2013): What are the health risks associated with mobile phones and their base stations. http://www.who.int/features/qa/30/en/ (online $\mathrm{Q}$ and $\mathrm{A})$.

Health risks associated with mobile phones use NCBI - $\quad$ NIH, https://www.ncbi.nlm.nih.gov/pmc/articles/PM C4350886/.

Center for Electrosmog Prevention (CEP), California suggested some ways to reduce cell phone radiation; http://www.emfhealth.com/articles-10tips.htm and http://www.cancer.gov/cancertopics/factsheet/ Risk/cellphones.

https://gp/g;<yW4ym;

http://www.envirochip.in/global-research/ https://www.envirochip.in/how-envirochipwork/

https://www2.deloitte.com/content/dam/Deloitt e/in/Documents/technology-mediatelecommunications/in-tmt-indian-towerindustry-noexp.pdf (Last accessed on March 29, 2017)

https://www.cancer.org/cancer/cancercauses/radiation-exposure/cellular-phonetowers.html.

The Indian Express News Service (October 22, 2016): Mobile towers cause no adverse effects on health. Department of Telecommunications Secretary, Express News Service.

Singh Jaskaran (May 15, 2017): India: Reevaluating the impact of mobile towers: A legal perspective, Mondaq - PSA (Legal Counselors). http://www.moneylife.in/article/protect-yourfamily-from-mobile-tower-radiation/45912.html. 